Available online on 15.7.2019 at http://ujpr.org
Universal Journal of Pharmaceutical Research
This is an open access article distributed under the terms of the Creative Commons Attribution-Non
Open access to Pharmaceutical research
Commercial Share Alike 4.0 License which permits unrestricted non commercial use,
provided the original work is properly cited
Volume 4, Issue 3, 2019

\title{
DETERMINATION OF RIFAMPICIN MONO-RESISTANCE MYCOBACTERIUM TUBERCULOSIS IN THE NATIONAL TUBERCULOSIS CONTROL PROGRAMME IN SANA'A CITY-YEMEN: A SIGNIFICANT PHENOMENON IN WAR REGION WITH HIGH PREVALENCE TUBERCLOISIS \\ Roqiaa Mohammed Ahmed Al-Hrazi ${ }^{1}{ }^{\mathbb{D}}$, Bushra Mohammed Jaadan ${ }^{2}{ }^{\mathbb{D}}$, Hassan A. Al-Shamahy ${ }^{1} \mathbb{D}$ \\ ${ }^{I}$ Medical Microbiology and Clinical Immunology Department, Faculty of Medicine and Health Sciences, Sana'a University, Republic of Yemen. \\ ${ }^{2}$ Medicinal Chemistry, Faculty of Pharmacy, Sana'a University, Republic of Yemen.
}

\section{ABSTRACT}

Objective: The current study was undertaken in Sana'a city, Yemen, which has one of the highest rates of Tuberculosis (TB) in the region. The aims of this retrospective study were determined the prevalence of true RIF's mono-resistance, using the gold standard of molecular assays comparing with culture based phenotypic drug susceptibility testing (DST), and determined the associated risk factors of contracting RF gene among Yemeni TB patients.

Methods: Patient's data were collected in a predesigned questionnaire which included demographic information and the relevant risk factors associated with RIF. All sputum specimens received were routinely cultured, and, underwent phenotypic drug susceptibility testing. DNA sequences specific for MTB and RIF were detected by automated molecular test.

Results: The total end treatment rate was 5.94\% of the total cases (11/185). MTB gene was positive for all cases which indicate more sensitive than sputum examination; 3.2\% of total patients show RIF's genes positive. Higher rate of RIF with male (5.4\%), and low in female patients $(1.8 \%)$. There was higher rate of RIF with age group 36-45 years $(8.7 \%)$ and $>15$ years $(7.1 \%)$. There was significant rate of RIF gene with after food drug taken $(\mathrm{RIF}=13.3 \%$, with Odds ratio $(\mathrm{OR})=6.4)$, and with DOTs program ( $\mathrm{RIF}=10 \%$, with $\mathrm{OR}=6.4)$. In addition, there was significant rate of RIF gene with one dose regimen $(11.8 \%, \mathrm{OR}=5.5)$.

Conclusion: In conclusion, this study reveals the presence of RIF- M. tuberculosis in Sana'a, Yemen and most of them were observed among patients who default treatment. This is considered as a threat to TB control programme and it is recommended that strategies should be put in place in order to ensure patients' compliance and monitoring of patients' response to TB treatment. Keywords: Mycobacterium tuberculosis (MTB), Rifampicin resistant (RIF), Sana'a, Tuberculosis (TB), Yemen.

Article Info: Received 8 May 2019; Revised 12 June; Accepted 8 July, Available online 15 July 2019

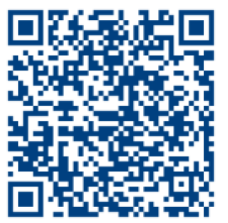
Cite this article-

Al-Hrazi RMA, Jaadan BM, Al-Shamahy HA. Determination of rifampicin mono-resistance Mycobacterium tuberculosis in the national tuberculosis control programme in Sana'a city-Yemen: a significant phenomenon in war region with high prevalence tubercloisis. Universal Journal of Pharm Research 2019; 4(3): 11-16.

DOI: https://doi.org/10.22270/ujpr.v4i3.266

Address for Correspondence:

Prof. Hassan A. Al-Shamahy, Faculty of Medicine and Heath Sciences, Sana'a University, P.O. Box 775 Sana'a, Yemen. Phone: +967-770299847, E-mail: shmahe@yemen.net.ye

\section{INTRODUCTION}

Globally in 2015, an estimated 480000 people developed multidrug-resistant TB (MDR-TB). TB incidence has fallen by an average of $1.5 \%$ per year since 2000 . This needs to accelerate to a $4-5 \%$ annual decline to reach the 2020 milestones of the "End TB Strategy". An estimated 49 million lives were saved through TB diagnosis and treatment between 2000 and 2015. Ending the TB epidemic by 2030 is among the health targets of the newly adopted Sustainable Development Goals ${ }^{1}$. When TB is detected and effectively treated, the disease is largely curable. However, in 2013, an estimated 9.0 million people developed TB and 1.5 million died from the disease, 360000 of whom were Human Immunodeficiency Virus (HIV) positive ${ }^{2}$. In Yemen, TB is considered one of the major infectious diseases recorded in the national disease list. A rapidly increasing population, poor quality health services, very low annual income of individuals and the whole country's poor economic status plus the Saudi-UAE's aggression are the most important factors responsible for the high incidence of TB in the country ${ }^{3,4}$. Drug-resistant Mycobacterium tuberculosis, including multidrug-resistant Mycobacterium tuberculosis (MDR-Mycobacterium tuberculosis, defined as resistance to at least isoniazid 
and rifampicin, the two most important first-line antiTB drugs) and extensively drug resistant TB (XDRMycobacterium tuberculosis, defined as MDRMycobacterium tuberculosis, plus resistance to any fluoroquinolones, such as ofloxacin or moxifloxacin, and to at least one of three injectable second-line drugs, amikacin, capreomycin, or kanamycin) has emerged as a serious threat to global health ${ }^{5}$.

Table 1: The demographic data of tuberculosis patient included in Rifampicin mono-resistance study, at the National Tuberculosis Control Programme.

\begin{tabular}{lccc}
\hline Age group & $\begin{array}{c}\text { Male } \mathbf{n = 7 4} \\
\mathbf{N}(\mathbf{\%})\end{array}$ & $\begin{array}{c}\text { Female } \\
\mathbf{n = 1 1 1} \\
\mathbf{N}(\mathbf{\%})\end{array}$ & $\begin{array}{c}\text { Total } \\
\mathbf{N}(\mathbf{\%})\end{array}$ \\
\hline$\leq 15$ year & $2(2.7)$ & $12(10.8)$ & $14(7.6)$ \\
16-25 year & $19(25.7)$ & $33(29.7)$ & $52(28.1)$ \\
26-35 year & $18(24.3 \%)$ & $33(29.7)$ & $51(27.6)$ \\
36-45 year & $10(13.5 \%)$ & $13(11.7)$ & $23(12.4)$ \\
$\geq$ 46 year & $25(33.8 \%)$ & $20(18)$ & $45(24.3)$ \\
Total & $\mathbf{7 4 ( 4 0 )}$ & $\mathbf{1 1 1}(\mathbf{6 0})$ & $\mathbf{1 8 5}(\mathbf{1 0 0})$ \\
Mean age & $38.6 \mathrm{yrs}$ & 31.1 & $34.15 \mathrm{yrs}$ \\
S.D & $17.9 \mathrm{yrs}$ & 14.8 & $16.5 \mathrm{yrs}$ \\
Medial & $35 \mathrm{yrs}$ & $30 \mathrm{yrs}$ & $30 \mathrm{yrs}$ \\
Mode & $20 \mathrm{yrs}$ & $30 \mathrm{yrs}$ & $30 \mathrm{yrs}$ \\
Min & $1 \mathrm{yrs}$ & $1 \mathrm{yrs}$ & $1 \mathrm{yrs}$ \\
Max & $75 \mathrm{yrs}$ & $70 \mathrm{yrs}$ & $75 \mathrm{yrs}$ \\
\hline
\end{tabular}

Rifampicin is one of the most important antituberculosis (anti-TB) antibiotics; it exerts its bactericidal activity by inhibiting the early steps of gene transcription by binding to the $\beta$-subunit of RNA polymerase (rpo $\beta$ ) encoded by the rpo $\beta$ gene $^{6}$. The control of TB has been impeded by the emergence of drug-resistant Mycobacterium tuberculosis strains ${ }^{7}$. The problem of TB has been compounded by the emergence of multi-drug resistance Mycobacterium tuberculosis and Human Immunodeficiency Virus (HIV). The development of resistance to rifampicin is due to mutations in a well-defined 81 base pair (bp) (27 codons) central region of the gene that encodes the $\hat{\mathrm{I}}^{2}$ subunit of RNA polymerase (rpo B). More than $96 \%$ of the rifampicin-resistant strains contain a mutation in this $81 \mathrm{bp}$ region of rpo $\beta$, thus facilitating a straight forward approach to detecting rifampicin resistance and/or MDR rapidly ${ }^{8}$. Despite low sensitivity in detection of Mycobacterium tuberculosis, acid-fast sputum smear remains the main diagnostic method in most countries, especially in resource-limited settings. In HIV infected patients with pulmonary TB, 24-61\% have acid-fast negative sputum smear. In 2011, WHO advice the wide use of Xpert Mycobacterium tuberculosis/Rifampicin assay, a fully automated diagnostic molecular test using real-time polymerase chain reaction (PCR) technology to simultaneously Mycobacterium Tuberculosis and rifampicin resistance mutations in the (rpo B) gene? Xpert Mycobacterium tuberculosis/Rifampicin is an automated polymerase chain reaction (PCR) test (molecular test) utilizing the GeneXpert ${ }^{\circledR}$ platform ${ }^{9,10}$. $\mathrm{Xpert}^{\circledR}$ MTB/RIF is a single test that can detect both Mycobacterium tuberculosis complex and rifampicin resistance within two hours after starting the test, with minimal hands-on technical time. The Xpert MTB/RIF limit of detection, "the lowest number of colony forming units per sample that can be reproducibly distinguished from negative samples with $95 \%$ confidence"11, is five genome copies of purified DNA per reaction or 131 colony forming units per $\mathrm{ml}$ in Mycobacterium tuberculosis spiked sputum $^{10}$. In comparison, identification of TB bacilli by microscopic examination requires at least 10,000 bacilli per $\mathrm{ml}$ of sputum $^{12}$.

Xpert MTB/RIF detects both live and dead bacteria ${ }^{13}$. The first nationwide prevalence survey on resistance to the four major anti-tuberculosis drugs in Yemen showed a relatively low prevalence of drug-resistant cases, but a high prevalence of multidrug resistance among new cases ${ }^{14}$. The current study aims were to determine prevalence of true RIF's mono-resistance, using the gold standard of molecular assays comparing with culture based phenotypic drug susceptibility testing (DST), and determine the associated risk factors of contracting RF gene among Yemeni TB patients.

\section{MATERIALS AND METHODS}

This cross-sectional laboratory study conducted among pulmonary patients attending the National Tuberculosis Control Programme (NTCP) in Sana'a city, Yemen. During the period from March, 2017 until December, 2017. Data was taken from each subject and collected in a predesigned questionnaire which included demographic information, detailed clinical history and risk factors associated with Rifampicin-mono-resistant Mycobacterium tuberculosis.

The patients were categorized to;

i. Patients that had previously received treatment in the same or another clinic but default after some time.

ii. Patients whose treatment history could not be assessed.

iii. Patients that visit the clinic for the first time.

iv. Patients who had relapse after completion of normal treatment plan.

Three sputum samples were collected from each patient, then one tested for acid fast bacilli, the second mixed with $2 \mathrm{ml}$ of buffer for genetic test (GeneXpert), and the third specimen for culture based phenotypic drug susceptibility testing (DST) . The GeneXpert System equipped with GX2.1 software/computer/ printer/barcode wand-reader and operator manual (Cepheid Inc, Sunnyvale, and USA).

The GenXpert MTB/RIF is an automated molecular test which detects DNA sequences specific for MTB and RIF's resistance by polymerase chain reaction with fully integrated sample processing in patients suspected of drug sensitive or multidrug resistant pulmonary tuberculosis. Also, the prevalence of true RIF monoresistance, using the gold standard of molecular assays (The GenXpert MTB/RIF) was comparing with culture based phenotypic drug susceptibility testing (DST). In addition, we determine the associated risk factors of contracting RF gene among Yemeni TB patients as described in result Table 4 and Table 5. 


\section{RESULTS}

Only $7.6 \%$ of tested individual were children $\leq 15$ years old, most of them were adults in age groups 1625 years $(28.1 \%), 26-35$ years $(27.6 \%), 36-45$ years $(12.4 \%)$ and $\geq 46 y e a r s(24.3 \%)$ (Table 1). Total end treatment rate (failure) was $5.94 \%$ of the total cases (11/185) (Table 3). Two point seven percentage of total patients show primary infection T.B (low) with low contagious, $24.3 \%$ show severe infections T.B with highly contagious, and $30.8 \%$ show very severe infections T.B with highly contagious (Table 2). MTB gene was positive for all cases which indicate more sensitive than sputum examination; $3.2 \%$ of total patients show RIF's genes positive, while $96.8 \%$ of total were sensitive to rifampicin (Table 3 ). Higher rate of RIF with male $(5.4 \%)$ with associated OR equal to 3.1 times, while RIF rate was $1.8 \%$ in female patients but the variation was not statistically significant ( $p$ $=0.17$ ). There was higher rate of RIF with age group $36-45$ years and $\leq 15$ years in which the rates of RIF gene were $8.7 \%$ and $7.1 \%$ respectively but the variation was not statistically significant $(p>0.05)$ (Table 4). There was significant rate of RIF gene with after food drug taken equal to $13.3 \%$, with OR equal to 6.4 times $(p=0.02)$, and with DOTs program equal to $10 \%$, with OR equal to 6.4 times $(\mathrm{p}=0.02)$. In addition, there was significant rate of RIF's gene with one dose regimen $(11.8 \%)$, with OR equal to 5.5 times $(p=0.03)$ (Table 4 and Table 5).

Table 2: The laboratory result of sputum specimens for AFB, MTB gene and RIF's gene for TB patients under treatment.

\begin{tabular}{|c|c|c|}
\hline Tests & $\begin{array}{l}\text { Number } \\
(\%)\end{array}$ & Interpretations \\
\hline \multicolumn{3}{|l|}{ AFB } \\
\hline a) 1-9 BPF & $5(2.7)$ & $\begin{array}{l}\text { primary infection } \mathrm{T} . \mathrm{B}(\mathrm{low}) \text { and low } \\
\text { contagious }\end{array}$ \\
\hline b) $+1 \mathrm{BPF}$ & $95(24.3)$ & Moderate infection T.B and low contagious \\
\hline c) $+2 \mathrm{BPF}$ & $57(30.8)$ & Severe infections T.B and Highly contagious \\
\hline d) $+3 \mathrm{BPF}$ & $49(26.5)$ & $\begin{array}{l}\text { Very severe infections T.B } \\
\text { and Highly contagious }\end{array}$ \\
\hline Negative & $24(15.7)$ & $\begin{array}{l}\text { The difficulty of coughing and removing } \\
\text { sputum is a recent infection with few } \\
\text { AFB. }\end{array}$ \\
\hline \multicolumn{3}{|l|}{ MTB gene } \\
\hline Positive & $185(100)$ & More sensitive than sputum examination \\
\hline Negative & $0(0)$ & Good diagnosis of suspicion \\
\hline $\begin{array}{l}\text { RIF genes: } \\
\text { RR (Resistant) }\end{array}$ & $6(3.2)$ & $\begin{array}{l}\text { Random use of treatment or treatment or use } \\
\text { of rifampicin therapy for non-TB disease }\end{array}$ \\
\hline SR (Sensitive) & $179(96.8)$ & $\begin{array}{l}\text { Resistant therapy may be a first-line } \\
\text { treatment other than rifampicin, e.g. } \\
\text { Isonazoid }\end{array}$ \\
\hline
\end{tabular}

Table 3: The frequency of different period of stop first line treatment due no response (failure) of T.B patients, attending NTCP in Sana'a city.

\begin{tabular}{lcl}
\hline $\begin{array}{l}\text { Period of stop previous T.B } \\
\text { treatment (failure) }\end{array}$ & Number (\%) & Interpretations \\
\hline 2 Months & $5(2.7)$ & All patients had previous T.B and \\
4 Months & $0(0)$ & stopped taking treatment. \\
6 Months & $3(1.62)$ & The shorter the treatment period, \\
9 Months & $3(1.62)$ & the greater the resistance. \\
Total stop (failure) & $11(5.94)$ & \\
\hline
\end{tabular}

\section{DISCUSSION}

There have been some good achievements over the past decade in tuberculosis control in the countries of the WHO Eastern Mediterranean region including Yemen. These countries have addressed the challenge of tuberculosis through implementation of the directly observed treatment, short-course (DOTS) strategy, with the case detection rate reaching $60 \%$ for new smear-positive cases, and an $86 \%$ treatment success rate. However, multidrug-resistant tuberculosis (MDR-TB) and extensively drug-resistant tuberculosis (XDR-TB) pose a threat to global and regional public health security and to efforts to reduce the global and regional burden of tuberculosis. The Beijing Call for
Action on Tuberculosis Control and Patient Care and the World Health Assembly resolution WHA62.15 (2009) on prevention and control of multidrug-resistant tuberculosis. Extensively drug-resistant tuberculosis ${ }^{15}$ recognizes the challenges posed by multidrug and extensively drug-resistant tuberculosis (M/XDR-TB) and call for urgent action to address the situation. The exact burden of multidrug resistance is not known in the region since drug resistance surveys have been conducted in only eight countries of the region excluding Yemen. MDR-TB is defined as resistance to both ionized (INH) and rifampicin (RIF), with or without resistance to other anti-tuberculosis drugs ${ }^{16}$. Unlike most other bacteria, resistance 
in Mycobacterium tuberculosis (MTB) develops primarily through mutations in chromosomal genes. These mutations develop spontaneously and are sustained in the bacterial population mainly through selective pressure with inappropriate treatment ${ }^{17,18}$. The exact burden of multidrug resistance in Yemen is not known, due to the limited number of national drug resistance surveys and surveillance, so that the current study was one of uncommon study in Yemen and the RFR rate in the current study was $3.2 \%$ (Table 2).

This rate $(3.2 \%)$ was slightly higher than $2 \%$ of the mean world rates that reported by WHO in the fourth
WHO global report on drug resistance, Anti-tuberculosis drug resistance in the world $^{15}$. Furthermore, the current MDR-TB rate $(3.2 \%)$ was higher than that reported from Lebanon, Morocco and Oman in which the rates were from $0.5 \%$ in Lebanon and Morocco to $1.3 \%$ in Oman ${ }^{19}$. Additionally, the present result was similar to that reported from Yemen previously in which the rate was $2.9 \%$, but lower than that from Jordan (5.4\%) among new cases of TB reported ${ }^{19}$.

Table 4: The association of resistant RIF's gene with age and sex of T.B patient under studied.

\begin{tabular}{|c|c|c|c|c|c|c|c|}
\hline \multirow[t]{2}{*}{ Characters } & \multicolumn{3}{|c|}{$\begin{array}{c}\text { RIF gene positive } \\
(n=6)\end{array}$} & \multirow[t]{2}{*}{ OR } & \multirow[t]{2}{*}{ CI } & \multirow[t]{2}{*}{$X^{2}$} & \multirow[t]{2}{*}{$P$} \\
\hline & No. & $\%$ & & & & & \\
\hline \multicolumn{8}{|l|}{ Sex } \\
\hline Male $(n=74)$ & & 4 & 5.4 & 3.1 & $0.6-17.5$ & 1.8 & 0.17 \\
\hline Female $(n=111)$ & & 2 & 1.8 & 0.32 & $0.05-1.7$ & 1.8 & 0.17 \\
\hline \multicolumn{8}{|l|}{ Age groups } \\
\hline $\begin{array}{l}\text { Less than } 15 y r s \\
(n=14)\end{array}$ & & 1 & 7.1 & 2.6 & $0.3-23$ & 0.7 & 0.39 \\
\hline $16-25 y r s(n=52)$ & & 2 & 3.8 & 1.3 & $0.2-7.2$ & 0.08 & 0.77 \\
\hline $26-35 \mathrm{yrs}(\mathrm{n}=51)$ & & 1 & 2 & 0.51 & $0.058-4.5$ & 0.36 & 0.54 \\
\hline $36-45$ yrs $(n=23)$ & & 2 & 8.7 & 3.8 & $0.64-21.8$ & 2.5 & 0.11 \\
\hline$\leq 46$ years $(\mathrm{n}=45)$ & & 0 & 0 & \multirow{2}{*}{\multicolumn{2}{|c|}{ undefined }} & 1.99 & 0.15 \\
\hline Total $n=185$ & & 6 & 3.2 & & & & \\
\hline
\end{tabular}

Chi square $\left(\mathrm{X}^{2}\right)$ and probability value $(\mathrm{P})$ were tested by Uncorrected test for cell $\geq 5$ and Fisher Exact test for cell $<5$.

Table 5: The associations of Rifampicin resistance with positive case in the house hold (contacts), time of drugs taken and DOTs.

\begin{tabular}{|c|c|c|c|c|c|c|}
\hline & \multicolumn{2}{|c|}{$\begin{array}{c}\text { Rifampicin } \\
\text { Resistance +ve }\end{array}$} & \multirow[t]{2}{*}{ OR } & \multirow[t]{2}{*}{$C I$} & \multirow[t]{2}{*}{$X^{2}$} & \multirow[t]{2}{*}{$P$} \\
\hline & No. & $\%$ & & & & \\
\hline \multicolumn{7}{|l|}{ House-hold case (contacts) } \\
\hline Yes $\quad(n=29)$ & 0 & 0 & 0.0 & $0.0-4.6$ & 0.25 & 0.61 \\
\hline No $\quad(n=155)$ & 6 & 3.9 & 0.0 & $0.22-1$ & 1.2 & 0.27 \\
\hline \multicolumn{7}{|l|}{ Time and drugs } \\
\hline Before eat $(n=2)$ & 0 & 0 & 0 & $0-170$ & 0.062 & 0.79 \\
\hline After food $(\mathrm{n}=15)$ & 2 & 13.3 & 6.4 & $1.1-38$ & 5.2 & 0.02 \\
\hline \multicolumn{7}{|l|}{ DOTs } \\
\hline Yes $(n=15)$ & 2 & 100 & 6.4 & $1.1-38$ & 5.2 & 0.02 \\
\hline No $(n=2)$ & 0 & 0 & 0.0 & $0.2-10$ & 5.0 & 0.02 \\
\hline \multicolumn{7}{|l|}{ Type of dose } \\
\hline One dose $(n=17)$ & 2 & 11.8 & 5.5 & $1-32.3$ & 4.3 & 0.03 \\
\hline Two doses $(n=0)$ & 0 & 0 & \multicolumn{4}{|c|}{ Undefined } \\
\hline Three doses $(n=1)$ & 0 & 0 & \multicolumn{4}{|c|}{ Undefined } \\
\hline
\end{tabular}

The resistance to RIF in current study is largely attributed to nucleotide substitutions in an 81-bp core region of the rpoB gene as confirmed by Telents ${ }^{17,18}$ and Pietzka et al., ${ }^{20}$. In contrast, resistance to INH occurs by mutations in several genes, in particular inh $\mathrm{A}$ and $k a t \mathrm{G}$, and to a lesser extent in ahpC, oxy $\mathrm{R}, k a s \mathrm{~A}$, furA and $n d h^{18,21}$. RIF's resistance in this study (3.2\%) is regarded as a proxy for MDR-TB as a large proportion of RIF resistant strains have INH resistance as described by Caws et al., ${ }^{22}$, Ramaswamg and Mussen $^{23}$, Rieder et al., ${ }^{24}$, Aziz ${ }^{25}$, Sau et al., ${ }^{26}$. What's more, theoretically, if RIF's resistance and MDR-TB were perfectly correlated, then detection of MDR-TB in Yemen would be sufficient with a single rapid test that detects RIF's resistance. As well, similarly, other parts of the world have also reported that RFR is not uncommon. Sanders et al. ${ }^{27}$ reported that levels of drug resistance in Bujumbura are higher than average for Africa and most worrying was the appearance of MDR-TB and RFR in new cases. Traore et al., ${ }^{28}$ studied a large number of MTB complex clinical isolates from diverse countries to detect RFR. Traore et $a l .,{ }^{28}$ reported a median of $4.6 \%$ RFR with the highest prevalence in Western Europe. Pablos-Mendez et al., ${ }^{29}$ performed anti-TB drug resistance surveillance (WHO) in 19 different countries and reported RFR in all. A 
median of $1.5 \%$ was noted, with the highest rate of $6.9 \%$ being reported from both Thailand and Dominican Republic. In comparison to the above studies, the current study reports a similar range of RFR.

In the current study, males were more likely to have RFR than females. This result is similar to that reported from Africa in which males have shown higher prevalence rates of RIF than females ${ }^{29}$. However, to the best of our knowledge, gender as a specific risk factor for RIF has not previously been documented in Yemen by others ${ }^{30}$. Although using age as risk factor is RIF, in the current study RIF was more likely to occur in the 36-45 year age group. It is well recognized that TB is more common in this age group and that RIF is more common in $3^{\text {rd }}$ and $4^{\text {th }}$ decades of life of patients as previously highlighted ${ }^{31-33}$. The current findings however are in contrast to Mukinda et al., who reported RIF higher in $>45$ year age group ${ }^{34}$. In spite of that the countries in the region including Yemen have been able to make a remarkable improvement in addressing the challenge of tuberculosis control through implementation of DOTS during the past decade in public health facilities; including primary health care centers with the treatment success rate for 2008 was $87 \%$. In the present study there was significant association between RF resistant positive cases and positive DOTS treatment in which the associated OR was 6.4 times, with $\mathrm{CI}=1.1-38$ and $\mathrm{PV}=0.02$ (Table 5). This negative effect for DOTS it can be explained by that resistance is a reflection of the mismanagement of tuberculosis cases. This mismanagement includes wrong diagnosis and delay of diagnosis, wrong or interrupted treatment, and the misuse of tuberculosis medicines, both first-line and second-line, such as through poor adherence to standardized treatment by private care providers, unregulated sale of antituberculosis medicines and utilization of tuberculosis medicines of unknown quality. In addition, there was difficulty of patients to reach centers for treatment due to the war situation in Yemen.

\section{CONCLUSION}

Significant number of the current patients ended first line treatment due no response, most of them in the first 2 months of starting treatment. MTB gene was positive for all TB cases which indicate high sensitive rate than sputum examination. Significant rate of RIF's genes positive was recorded in this study. There was a significant high rate of RIF's gene with previous TB infection. Great risk of develop RIF gene with DOTs program of treatment. The emergence of RF-resistant TB strains in Yemen would make the treatment of TB infections more difficult and increase the complications of tuberculosis. As accurate susceptibility data are crucial for appropriate therapy decisions, so it should be recommended that microbiology laboratories screen for $\mathrm{RF}$ in clinical isolates before starting treatment. Currently, no single Yemen surveillance study can provide estimates of the burden of all factors lead to wide spread of TB drug resistant across acute care TB patient populations.

\section{ACKNOWLEDGEMENTS}

The authors would like to acknowledge Faculty of Medicine and Health Sciences, Sana'a University and the National Tuberculosis Control Programme in Sana'a city-Yemen for support and provided working space and materials.

\section{AUTHOR'S CONTRIBUTION}

This research work is part of M.Sc. thesis. The candidate is the first author (RMH) who conducted the works and the experiments and wrote up the thesis. The corresponding author (HAA) supervised the experimental work, revised and edited the thesis draft and the manuscript. (BMJ) was co-advisor of the work helped in revised, edited the thesis draft and the manuscript and in the laboratory works.

\section{CONFLICT OF INTEREST}

No conflict of interest associated with this work

\section{REFERENCES}

1. WHO. Guideline for Treatment of tuberculosis: guidelines for national programmes. 2010;

http://www.who.int/tb/features_archive/new_treatment_guid elines_may2010/en/; access date 24 June 2019.

2. WHO. Guidelines on the management of latent tuberculosis infection. 2015; ISBN: $\begin{array}{llllll}978 & 92 & 4 & 154890 & 8 .\end{array}$ http://www.who.int/tb/publications/latent-tuberculosisinfection/en/; access date 24 June 2019.

3. Abassi A, Mansourian AR. Efficacy of DOTs strategies in treatment of respiratory tuberculosis in Gorgan, Islamic Republic of Iran. Eastern Medit Health J 2007; 13 (3): 664 669. PMID: 17687840

4. MHP. News letter Ministry of Health and Population, Sana'a, Yemen, 2019

5. Zumla A, Abubakar I, Raviglione M, et al. Drug-resistant tuberculosis - current dilemmas, unanswered questions, challenges, and priority needs. Infectious Diseases 2012; 205 (2):S228-40. https://doi.org/10.1093/infdis/jir858

6. Campbell EA, Korzheva N, Mustaev A, et al. Structural mechanism for rifampicin inhibition of bacterial RNA polymerase Cell 2001; 104: 901-12. https://doi.org/10.1016/S0092-8674(01)00286-0

7. Kan M. Current status of tuberculosis in Taiwan. Epidemiol Bull Cent Dis Control Dep Health ROC 2000; 16:44-7. https://doi.org/10.1099/jmm.0.05045-0

8. Zhang Y, Telenti A. Genetics of drug resistance in Mycobacterium tuberculosis. In: Hatful GF, Jacobs WR Jr, eds. Molecular Genetics of Mycobacteria. Washington DC: ASM Press; 2000; 235-254. https://doi.org/10.1136/thx.53.9.793

9. Blakemore R, Story E, Helb D, et al. Evaluation of the analytical performance of the Xpert MTB/RIF assay. Clinical Microbiology 2010; 48: 2495-501. https://doi.org/10.1128/JCM.00128-10

10. Helb D, Jones M, Story E, et al. Rapid detection of Mycobacterium tuberculosis and rifampin resistance by use of on-demand, near-patient technology. Clinical Microbiology 2010; 48:22937. https://doi.org/10.1128/JCM.01463-09

11. Cepheid. Brochure: Xpert®MTB/RIF. Two-hour detection of MTB and resistance to rifampicin. Broch R9'EU.pdf. Sunnyvale, Accessed (17) 2019; 1-http://www.cepheid.com/ media/files/eu/brochures/XpertMTB.

12. Toman K. How many bacilli are present in a sputum specimen found positive by smear microscopy? In: Frieden. $\mathrm{T}$ editor(s). Toman's tuberculosis: case detection, treatment, and monitoring-questions and answers. WHO/HTM/ TB/2004.334. $2^{\text {nd }}$ Edition. Geneva: World Health Organization 2004; 11-13. 
13. Miotto P, Bigoni S, Migliori GB, et al. Early tuberculosis treatment monitoring by $\operatorname{Xpert(R)~MTB/RIF.~European~}$ Respiratory 2012; 39 (5):1269-71. https://doi.org/10.1183/09031936.00124711

14. Al-Akhali A1, Ohkado A, Fujiki A, et al. Nationwide survey on the prevalence of anti-tuberculosis drug resistance in the Republic of Yemen. International 2007; 11 (12):1328-33. PMID: 18034954

15. WHO. 2009. Anti-tuberculosis drug resistance in the world: fourth global report. https://www.who.int/tb/publications/tbdrugresistance-fourthreport/en/ access date 24 June 2019

16. Jaramillo E. Guidelines for the programmatic management of drug-resistant tuberculosis: emergency update 2008: World Health Organization.

17. Telenti A, Imboden $\mathrm{P}$, Marchesi F, et al. Detection of rifampicin-resistance mutations in Mycobacterium tuberculosis. The Lancet 1993; 341: 647-651. https://doi.org/10.1016/0140-6736(93)90417-F

18. Telenti A, Honore N, Bernasconi Ca, et al. Genotypic assessment of isoniazid and rifampin resistance in Mycobacterium tuberculosis: a blind study at reference laboratory level. J Clin Microbiol 1997; 35: 719-723. PMID: 9041419

19. WHO. 2016. Strategic plan for the prevention and control of multidrug-resistant and extensively drug-resistant tuberculosis in the eastern mediterranean region (20102015).

20. Pietzka AT, Indra A, Stöger A, et al. Rapid identification of multidrug-resistant Mycobacterium tuberculosis isolates by rpo B gene scanning using high-resolution melting curve PCR analysis. J Antimicro Chemo 2009; 63:1121-1127. https://doi.org/10.1093/jac/dkp124

21. Kapur V, Li LL, Iordanescu S, et al. Characterization by automated DNA sequencing of mutations in the gene (rpoB) encoding the RNA polymerase beta subunit in rifampinresistant Mycobacterium tuberculosis strains from New York City and Texas. J Clin Microbiol 1994; 32: 1095-1098. PMID: 8027320

22. Caws M, Duy PM, Tho DQ, et al. Mutations prevalent among rifampin-and isoniazid-resistant Mycobacterium tuberculosis isolates from a hospital in Vietnam. J Clin micro 2006; 44: 2333-2337. https://doi.org/10.1128/JCM.00330-06

23. Ramaswamy S, Musser J. Molecular genetic basis of antimicrobial agent resistance in Mycobacterium tuberculosis: 1998 update. Tubercle and Lung Disease 1998; 79: 3-29. https://doi.org/10.1054/tuld.1998.0002
24. Rieder H, Av D, Kam K, Kim S, et al. Priorities for tuberculosis bacteriology services in low-income countries: International union against tuberculosis and lung disease 2007. Paris, France https://doi.org/10.1371/journal.pone.0077712

25. Aziz MA. Anti-tuberculosis drug resistance in the world: third global report: the WHO/IUATLD Global Project on Anti-tuberculosis Drug Resistance Surveillance, 1999-2002: World Health Organization 2004.

26. Sam IC, Drobniewski F, More P, et al. Mycobacterium tuberculosis and rifampin resistance, United Kingdom. Emerging Infect Dis 2006; 12: 752.

27. Sanders M, Van Deun A, Ntakirutimana D, et al. Rifampicin mono-resistant Mycobacterium tuberculosis in Bujumbura, Burundi: results of a drug resistance survey. The Int $\mathrm{J}$ Tuberculosis Lung Dis 2006; 10: 178-183.

28. Traore H, Fissette K, Bastian I, et al. Detection of rifampicin resistance in Mycobacterium tuberculosis isolates from diverse countries by a commercial line probe assay as an initial indicator of multidrug resistance Technical Note. The Int J Tuberculosis Lung Dis 2000; 4: 481-484.

29. Pablos-Méndez A, Raviglione MC, Laszlo A, et al. Global surveillance for anti-tuberculosis-drug resistance, 19941997. New England J Med 1998; 338: 1641-1649. https://doi.org/10.5588/ijtld.11.0542

30. Al-Mahbashi AA, Mukhtar MM, Mahgoub ES. Molecular typing of Mycobacterium spp. isolates from Yemeni tuberculosis patients. EMHJ 2013; 19(11):1-6. https://doi.org/10.1155/2014/645802

31. Ridzon R, Whitney CG, McKenna MT, Taylor JP, Ashkar $\mathrm{SH}$, et al. Risk factors for rifampin mono-resistant tuberculosis. American J Resp Crit Care Med 1998; 157: 1881-1884. https://doi.org/10.1164/ajrccm.157.6.9712009

32. Weltman A, Righi S, Di Ferdinando G Jr, et al. Rifampicinresistant Mycobacterium tuberculosis. The Lancet 1995; 345: 1513. https://doi.org/10.5588/ijtld.11.0542

33. Nolan CM, Williams DL, Cave MD, et al. Evolution of rifampin resistance in human immunodeficiency virusassociated tuberculosis. American J Resp Crit Care Med 1995; 152: 1067-1071. https://doi.org/10.1371/journal.pone.0077712

34. Mukinda F, Theron D, Van Der Spuy G, et al. Rise in rifampicin-monoresistant tuberculosis in Western Cape, South Africa. The Int J Tuber Lung Disease 2012; 16: 196202. https://doi.org/10.5588/ijtld.11.0116 